Socially responsible investing in the global market: The performance of US and European funds

\author{
Maria Céu Cortez \\ mcortez@eeg.uminho.pt \\ Florinda Silva $(*)$ \\ fsilva@eeg.uminho.pt \\ Nelson Areal \\ nareal@eeg.uminho.pt \\ NEGE - Management Research Unit \\ University of Minho \\ Campus de Gualtar, 4710-057 Braga, Portugal \\ Tel: +351253604554 \\ Fax: +351 253601380
}

(*) Corresponding author

Keywords: Fund performance evaluation, Socially responsible mutual funds, Global funds, Factor Models, Conditional Models 


\title{
Socially responsible investing in the global market: The performance of US and European funds
}

\begin{abstract}
This paper investigates the style and performance of US and European global socially responsible funds. Several specifications of the return generating process are applied as well as their corresponding conditional versions.

Most European global socially responsible funds do not show significant performance differences in relation to both conventional benchmarks and socially responsible benchmarks. US funds and Austrian funds show evidence of underperformance. By applying conditional models, we find evidence of time-varying betas, but not of time-varying alphas. With respect to investment style, we find evidence that socially responsible funds are strongly exposed to small cap and growth stocks. While these results are consistent with previous studies, they uncover some misclassification issues in these funds. Finally, we also document a significant home bias for global socially responsible funds.
\end{abstract}




\section{Introduction}

There is growing evidence that investors are willing to incorporate ethical and social criteria to their investment decisions. According to recent statistics, roughly $11 \%$ and $17 \%$ of assets under professional management in the US and Europe, respectively, are involved in socially responsible investments (SRIs). ${ }^{1}$ Furthermore, socially SRIs have been growing at a substantially higher rate than conventional investments. In particular, socially responsible funds constitute an attractive response to investors' social concerns and are increasingly moving towards the mainstream of the investment area. The financial performance of these funds is therefore a topic of interest to both practitioners and academics, which have been attempting to understand the effects of social screening in portfolio performance. This paper contributes to the debate on the issue of whether it is possible to do well by doing good, i.e., if it is possible to consider social issues without sacrificing financial performance.

Empirical evidence on socially responsible funds has typically shown that there are no statistical differences between the performance of these funds and their conventional peers. However, the first studies on socially responsible funds have focused on relatively small samples of funds throughout relatively short periods of time and using mainly traditional performance measures. The gap between SRI investigations and research in the broader area of conventional fund performance was overwhelming until the mid 2000s. However, a number of studies have recently attempted to overcome these shortcomings in socially responsible fund performance research. Bauer et al. (2005), in a study of socially responsible funds for the US, UK and German markets, consider both multi-factor-models and conditional measures of

\footnotetext{
${ }^{1}$ Source: Eurosif 2008 European SRI study and SIF 2007 report on SRI trends in the United States. Eurosif is the European Social Investment Forum "whose mission is to address sustainability through financial markets". SIF is the US Social Investment Forum whose activities are "dedicated to advancing the concept, practice, and the growth of socially and environmentally responsible investing (SRI)".
} 
fund performance. Other studies that consider more recent methodologies in evaluating socially screened funds include Gregory and Whittaker (2007) on the UK market, Cortez et al. (2009) on European socially responsible funds and Renneboog et al. (2008) on a large sample covering the world market.

As international financial markets have become increasingly integrated, global funds experienced a substantial growth. These funds invest in the worldwide market and aim to exploit the potential benefit from international diversification. In the particular case of socially responsible funds, the issue of diversification can be quite important. In fact, one of the arguments that is usually used to hypothesize why socially responsible funds should underperform conventional funds is that these portfolios are based on a more restricted investment opportunity set. By diversifying internationally, socially responsible funds may increase their opportunity set and overcome this potential limitation. However, the performance of global socially responsible mutual funds is relatively unexplored in the literature.

In this context, the objective of the current paper is threefold. First, we aim to investigate the performance of socially responsible funds that invest globally, controlling for investment styles and allowing for time variation in betas and alphas. Our sample is composed of funds from several European countries as well as from the US market. Although some previous studies examine the performance of global socially responsible funds as a part of a larger sample including also domestic socially responsible funds (e.g., Bauer et al., 2005; Gregory and Whittaker, 2007) this is the first study to perform a comprehensive analysis on International or Global socially responsible funds. Secondly, by using multi-factor models that control for size and book-to-market, we analyze the investment style pursued by global socially responsible funds. Finally, we investigate possible home bias among funds that invest globally. 
Our findings suggest that global socially responsible funds in most European markets do not exhibit significant performance differences in comparison to both conventional benchmarks and socially responsible benchmarks. On the contrary, US funds, and to a lesser extent, Austrian funds, show evidence of underperformance, particularly when the model controls for value and size effects and for home bias. Furthermore, the results from the conditional models suggest evidence of time-varying betas, but not of time-varying alphas. Regarding the investment style of the funds, we find evidence that global socially responsible funds are strongly exposed to small cap and growth stocks. While these results are consistent with previous studies, they reveal some misclassification issues in global socially responsible funds, given that our sample is composed mostly by funds classified as global large cap blend funds. Finally, our results show a significant home bias for global socially responsible funds. Although these funds are considered international or global funds, this home bias implies that investors in these funds may not fully benefit from the potential diversification effects that could arise from international investing.

The remainder of this paper is organized as follows. Section 2 discusses the literature on the performance of socially responsible funds. Section 3 outlines the methodology used to assess fund performance. Section 4 describes the data while section 5 discusses the empirical results. Finally, section 6 summarizes the main results and presents some concluding remarks.

\section{Prior Research}

Theoretically, two contrasting arguments have competed to explain the impact of social screens on the financial performance of mutual funds. On the one hand, arguments based on portfolio theory suggest that the construction of portfolios from a 
restricted universe of stocks will limit the benefits of diversification (Rudd, 1981). Furthermore, the additional costs of monitoring social performance will also lead to lower returns. Accordingly, these funds should exhibit underperformance relative to conventional portfolios. On the other hand, proponents of socially responsible investments argue that social screens represent filters that enable the identification and selection of firms with higher quality of management relative to their less responsible competitors. As a consequence, portfolios composed of socially responsible stocks will benefit from improved performance in the long run (e.g. Hill et al., 2007; Kempf and Osthoff, 2007).

In general, empirical studies have typically shown that the performance of socially responsible funds is similar to the performance of conventional funds. However, there are some theoretical and methodological shortcomings associated with these studies, such as potential benchmark problems that arise in the context of the single-index measures of performance that are used. In fact, studies on the US market, including Hamilton et al. (1993), Reyes and Grieb (1998), Goldreyer and Diltz (1999), Statman (2000), and Bello (2005) are, in general, limited to traditional CAPMbased measures of performance; these are currently recognized as inappropriate to measure fund performance. A series of studies on UK "ethical" funds (Luther et al., 1992; Luther and Matatko, 1994; Mallin et al., 1995; Gregory et al., 1997) have uncovered a small size bias in socially responsible funds, which clearly suggests that multi-factor models should be used to analyze the performance of these types of funds. Studies on the performance of social funds includes data from several other individual countries, such as, for instance, Holland (Scholtens, 2005), Australia (Bauer et al., 2006), and Canada (Bauer et al., 2007). In general, these studies have not observed 
either overperformance or underperformance of socially responsible funds relative to their conventional counterparts.

A set of other studies has performed a comparative analysis of the performance of socially responsible funds in more than one market. Kreander et al. (2002) were the first to analyze a considerable number of European markets (UK, Sweden, Germany, Netherlands, Norway, Switzerland and Belgium). Schröder (2004) and Bauer et al. (2005), besides considering the US market, also analyze the performance of socially responsible funds in other European markets. The former focuses on German and Swiss funds, while the latter use a larger sample composed of UK and German funds. Cortez et al. (2009) investigate the performance of socially responsible funds for seven European countries (Austria, Belgium, France, Germany, Italy, the Netherlands and UK).

Only recently have some studies provided empirical evidence on the basis of more robust performance measures and for longer time periods. ${ }^{2}$ Bauer et al. (2005), Bauer et al. (2006), Bauer et al. (2007) and Cortez et al. (2009) use multifactor models that control for investment style and/or conditional models of performance evaluation. In general, these studies come to the conclusion that socially screened funds do not underperform their unscreened peers.

The empirical evidence on the performance of socially responsible funds has revealed some common findings. First, socially responsible funds pursue different investment strategies than conventional funds. Indeed, as Luther et al. (1992) first documented, socially responsible funds seem to be more exposed to small capitalization stocks. This type of bias, which seems stronger for European than American socially responsible funds, has also been documented by Schröder

\footnotetext{
2 In fact, other types of limitations of previous studies are the reduced sample size and short time period of analysis (e.g., Kreander et al., 2002; Scholtens, 2005).
} 
(2004), Scholtens (2005) and Bauer et al. (2005). Furthermore, Bauer et al. (2005) show that socially responsible funds are biased towards growth stocks. A potential explanation for these results is that value stocks usually represent higher environmental risks and are therefore more likely to be excluded from socially responsible funds. ${ }^{3}$ Benson et al. (2006) also find evidence that American socially responsible funds are more exposed to telecommunications stocks than to utilities. On the other hand, Scholtens (2005) and Bauer et al. (2006) observe that Dutch and Australian socially responsible funds are tilted towards value stocks. These results are in line with Schröder (2004), who finds that American socially responsible funds are more oriented to information technology stocks relative to their German and Swiss peers, which tend to be more oriented towards utilities. Empirical evidence therefore suggests the existence of geographical differences in the investment style of socially responsible funds.

A second common finding of the extant studies is that socially responsible funds are more exposed to conventional indices than to socially responsible indices (Bauer et al., 2005; Bauer et al., 2006; and Cortez et al., 2009) ${ }^{4}$. This finding seems rather puzzling. Conceptually, indices constructed using social screens should be better able to explain returns of funds that are also constructed using similar social screens.

Finally, recent studies using the conditional approach to performance evaluation have shown evidence of time-varying betas in socially responsible funds (Bauer et al., 2006; Bauer et al., 2007; and Cortez et al., 2009). According to these studies, the results also seem to suggest that the conditional alphas are slightly better than their unconditional counterparts. Nonetheless, the differences between the conditional alphas of screened and unscreened portfolios remain statistically insignificant.

\footnotetext{
3 This explanation is consistent with Statman (2006), which observes that socially responsible indices have higher proportions of information and telecommunications technology stocks relative to conventional indices, while the latter have higher proportions of industrial stocks.

${ }^{4}$ When examining a large set of socially responsible indices, Schröder (2007) concludes that these indices also have a higher risk compared to conventional benchmarks.
} 


\section{Methodology}

The well known Jensen's (1968) alpha is used as an unconditional measure of performance. This measure is the intercept $\left(\alpha_{p}\right)$ of the CAPM-based following regression:

$$
r_{p, t}=\alpha_{p}+\beta_{p} r_{m, t}+\varepsilon_{p, t}
$$

where $r_{p, t}$ represents the excess return of portfolio $p$ over period $t, r_{m, t}$ represents the market's excess return during the same period, $\beta_{p}$ is the systematic risk of the portfolio and $\varepsilon_{p, t}$ is the error term. A statistically significant positive (negative) alpha indicates a superior (inferior) performance of the fund manager in relation to the market. In this model, both alpha and beta are constrained to be constant.

The conditional approach of Christopherson et al. (1998) extends the model of Ferson and Schadt (1996) by allowing both alpha and beta to be time-varying. ${ }^{5}$ This reflects the possibility that manager's performance and portfolio risk can change with economic conditions. These conditional alphas and betas are defined as linear functions of a vector of predetermined information variables, $Z_{t-1}$, that represents the public information available at time $t-1$ for predicting returns at time $t$. In this conditional model, equation [1] becomes:

$$
r_{p, t}=\alpha_{0 p}+\mathbf{A}_{p}^{\prime} \mathbf{z}_{t-1}+\beta_{0 p} r_{m, t}+\boldsymbol{\beta}_{p}^{\prime}\left(\mathbf{z}_{t-1} r_{m, t}\right)+\varepsilon_{p, t}
$$

where $\alpha_{0 p}$ is an average alpha, the vector $A_{p}^{\prime}$ measures the response of the conditional alpha to the lagged information variables, $\beta_{0 p}$ is the average conditional beta and the

\footnotetext{
5 The conditional model of Ferson and Schadt (1996) only incorporates time-varying betas. However, Ferson et al. (2008) show that the time-varying alpha term should be included in the regression in order to obtain unbiased estimates of conditional betas.
} 
vector $\beta_{p}^{\prime}$ measures the response of the conditional beta to the same information variables.

Although there is no consensus on the exact form of the return-generating process nor on the number of influences that should be included in it, there is a general agreement in the literature (e.g.: Elton et al., 1996; Carhart, 1997) that multi-factor models are a much more useful characterization of portfolio returns than single-index models. The generalization of the conditional approach to multi-factor models is straightforward. Replacing the market return by a set of factor returns, the above equation can be expressed as:

$$
r_{p, t}=\alpha_{0 p}+\mathbf{A}_{p}^{\prime} \mathbf{z}_{t-1}+\boldsymbol{\beta}_{0 p}^{\prime} \mathbf{F}_{k, t}+\boldsymbol{\beta}_{p}^{\prime}\left(\mathbf{z}_{t-1} \mathbf{F}_{k, t}\right)+\varepsilon_{p, t}
$$

where $\boldsymbol{\beta}_{0 p}^{\prime}$ is the vector of average conditional betas and $\mathbf{F}_{\mathrm{k}, \mathrm{t}}$ is the vector of factor returns.

\section{Data}

\subsection{Overview of the socially responsible fund market: Europe vs US}

Although socially responsible funds have been gaining worldwide popularity, the US is clearly the most developed market for these types of investments. Since the launch of the first socially responsible fund in the US (1971) and the UK (1984), the socially responsible mutual fund market has been growing at a high rate, not only in terms of number of funds but also in terms of total assets under management. In Europe, the number of socially responsible funds has grown from 159 in 1999 to 437 in June 2007 and assets under management have increased from around 11 billion euros to more than 48 billion euros. In the US, the number of socially responsible funds has increased 
from 168 in 1999 to 260 at the end of 2007 and total assets has risen from 159 billion US dollars to 202 billion US dollars. Despite this development, the socially responsible fund market still represents a small percentage of the broad mutual fund market: less than $1 \%$ in Europe and around $1.7 \%$ in the US. ${ }^{6}$

Regarding the type of social screens used there are some differences between US and European funds. While European funds are more focused on positive criteria, most US funds employ negative or exclusionary screens (Louche and Lydenberg, 2006). Indeed, about a quarter of US socially responsible funds employ negative screening against one of the "sin" factors (typically, tobacco). Furthermore, there are also differences in terms of positive or qualitative screens used. For example, US funds are more active in terms of shareholder advocacy and on community investing than their European peers. $^{7}$

\subsection{Fund Returns}

Our sample of Global or World equity socially responsible funds includes the most representative markets in Europe as well as the US market. For the European markets we identify the funds from the SRI funds service database of Avanzi research/Vigeo Italia. ${ }^{8}$ For the US, these funds are identified from the Social Investment Forum. In the case of funds with different share classes, we only select the oldest one. In total, the sample is composed of 39 funds for European markets (Austria, Belgium, France, Germany, Italy, Netherlands and the UK) and 7 US funds over the period from August 1996 to August 2008. For the European markets the classification of the funds

\footnotetext{
${ }^{6}$ According to the SIF "2007 Report on Socially Responsible Investing Trends in the United States" and the "Green, social and ethical funds in Europe. 2007 Review" by Vigeo and Avanzi SRI research.

${ }^{7}$ For further details concerning differences in socially responsible investing between Europe and the United States see Louche and Lydenberg (2006).

${ }^{8}$ At the end of 2006 Avanzi SRI Research was integrated into Vigeo. Vigeo is the leading European Corporate Social Responsibility Ratings Agency. We can access the list of European socially responsible funds through the Avanzi SRI research platform (the free service of SRI funds service) at http://customer.morningstareurope.com/it/avanzi/fundselect/index free.aspx.
} 
follows the scheme developed by Morningstar Europe. This categorisation reflects the different investment styles that are typically used by fund managers: from large to small cap stocks and from value to growth stocks. Most of the funds in our sample are classified as Global Large-cap Blend equity (23 funds). The remaining funds include four Global Large-cap Growth equity funds, four Global Large-cap Value equity funds and seven Global Small/Mid-cap equity funds.

Both surviving and nonsurviving funds are included. ${ }^{9}$ Monthly returns, in local currency (UK pounds, US dollars and Euros for the EMU countries), were collected from Datastream. To be included in the sample, funds were required to have at least 24 monthly observations. Monthly continuously compound returns are net of management fees but gross of load fees. Excess returns are computed relative to the risk-free rate, proxied by the corresponding one-month Euro-Deposit rates.

Table 1 reports the main descriptive statistics of our sample of funds over the period from August 1996 to August 2008. Equally weighted portfolios of all funds for each country are analyzed. As can be observed, only global funds from Belgium and the Netherlands earned positive mean excess returns comparable to those obtained by well known conventional and socially responsible world indices. German funds present the highest volatility and although the mean excess return is positive it is quite small. In Austria, France, Italy, the UK and the US, global SRI funds exhibit, on average, negative excess returns. Regarding the world market indices, the socially responsible indices present, in all the cases, a higher mean excess return than those shown by conventional indices.

\section{[Insert Table 1 here]}

\footnotetext{
${ }^{9}$ Although non-surviving funds are considered we cannot state that our sample is free from survivorship bias. We have been able of identify one dead fund in European markets and four in the US.
} 


\subsection{Benchmark returns}

For the single-index model, both conventional and socially responsible indices are used as benchmarks. The MSCI AC World index and the FTSE4Good Global are used as the conventional and socially responsible benchmarks, respectively.

In the case of the multi-index models we consider several alternative specifications:

1) The first alternative considers the two Fama and French (1998) international factors: a world market factor plus a world value factor. The data on these factors is available on Kenneth French's webpage and are converted into other currencies (Euro and UK pound) by applying the appropriate exchanges rates. ${ }^{10}$

2) In addition to the world market return, the second specification includes two other factors measuring value and size. In this version, we measure value as the return difference between the MSCI AC World Value index and the MSCI AC World Growth index, and size as the return difference between the MSCI AC World Small index and the MSCI AC World Large index. All these series are collected from Datastream.

3) The third specification follows Carhart's (1997) 4-factor model, using the US factors as proxies for world factors. ${ }^{11}$ The data on these factors are also available on Kenneth French's webpage. When other than US dollar currency is necessary, we transform these factors into other currencies (Euro and UK pound) by using the appropriate exchange rates.

4) In order to control for the possibility of home bias (a common issue in International funds) we also consider the above models with an additional local

\footnotetext{
10 Available at http://mba.tuck.dartmouth.edu/pages/faculty/ken.french/data_library.html. The series corresponding to the world value factor (the difference between the value and the growth index portfolios) is the one formed on the basis of book-to-market ratio.

${ }^{11}$ The use of US factors as proxies for world factors can also be found in Gregory and Whittaker (2007) and Chua et al. (2008).
} 
factor measured as the return difference between the local market index and the world market index. ${ }^{12}$

\subsection{Information variables}

For the conditional models, we consider lagged information variables that previous research has found to be useful in predicting stock returns (Keim and Stambaugh, 1986; Fama and French, 1989; Avramov and Chordia, 2006). As our analysis focuses on funds investing globally, we use global information variables instead of the most common local ones. ${ }^{13}$ The US market is used as the proxy for the global market. Two information variables are considered: a short-term rate and the dividend yield. ${ }^{14}$ The yield on a constant-maturity 3-month US Treasury bill is used as the short-term rate. The dividend yield is based on the FTSE All-World Index. As these variables tend to be highly persistent, a potential problem that might arise is the bias resulting from spurious regressions. To avoid this problem, we detrended these series by subtracting a 12-month moving average, a procedure suggested by Ferson et al. (2003). These variables are used in their corresponding mean zero values (Bernhardt and Jung, 1979) in order to minimize possible scale effects on the results.

\section{Empirical results}

\subsection{Single-index models}

Performance estimates obtained from alternative unconditional single index models are reported in Table 2. Panel A presents regressions estimates for equally

\footnotetext{
${ }^{12}$ Local market refers to the country where each fund is based. As local market indices we consider the corresponding MSCI country indices.

${ }^{13}$ The increasing degree of integration of financial markets is an additional argument to support the use of global information variables.

${ }^{14}$ These are standard information variables used in many of the empirical studies to date, as they are considered as measures of the state of the economy. These two variables were also used by Ferson and Warther (1996) and Christopherson et al. (1999).
} 
weighted portfolios of funds considering a conventional index as the benchmark (the MSCI AC World index), while Panel B presents regressions estimates obtained with a socially responsible index, the FTSE4Good Global index, as the benchmark. ${ }^{15}$ Results in Panel A show that global socially responsible funds in most of the countries achieve negative alphas. These, however, are only statistically significant in the case of Austrian (at the 10\% level) and US funds (at the 1\% level). Funds in Belgium and in the Netherlands exhibit positive alphas, although they are not statistically different from zero. The conventional benchmark used explains a large percentage of fund excess returns except for the case of German funds. ${ }^{16}$

\section{[Insert Table 2 here]}

When a socially responsible index is used as the benchmark, the results are similar. In only one case (French funds) did the alpha change from negative to positive, although neither are statistically significant. Furthermore, in general we obtain lower estimates of betas and lower adjusted coefficients of determinations $\left(R^{2}\right)$. These findings are consistent with those reported in Bauer et al. (2005), Bauer et al. (2006) and Cortez, et al. (2009) in the sense that socially responsible funds are more exposed to conventional indices than to socially responsible indices.

In terms of individual fund estimates, summarized in Table 3, we observe that when the conventional benchmark is used, 32 funds (out of the 46 that are included in our sample) exhibit negative alphas; of these 7 are statistically significant. Only one alpha is positive and statistically significant. A somewhat more favourable result is

\footnotetext{
${ }^{15}$ We have also considered the FTSE All-World index as an alternative for the conventional benchmark. Similar results were obtained and thus not reported in this paper.

${ }^{16}$ The lower $\mathrm{R}^{2}$ of the portfolio of German funds seems to be driven by a specific fund whose policy is directed to investing in environmental friendly companies.
} 
obtained with the socially responsible benchmark, with 20 and 26 funds presenting positive and negative alphas, respectively. Only one of the positive and 5 of the negative alphas are statistically significant.

\section{[Insert Table 3 here]}

\subsection{Multi-index models}

The performance of our sample of global socially responsible funds is also evaluated considering different multi-index models as described in the previous section. Table 4 compares the results of the first three multi-index models, each one presented in a different panel (Panel A, Panel B and Panel C, respectively). Panel A presents the regressions' estimates for the model with the two international factors of Fama and French (1998): a world market factor plus a world value factor. Panel B reports the regressions' estimates for the 3-factor model which includes, in addition to the world market index, two other factors: a world value factor and a world size factor. Panel C reports the regressions estimates for the 4-factor model. Following Carhart (1997), this model includes the three standard Fama-French factors plus a momentum factor. In these models we consistently measure the world market factor by the excess return on the MSCI AC World index. ${ }^{17}$

Analyzing Panel A, we can observe that the international value factor (measured by the international factor of Fama and French) does not seem to be an important factor in explaining excess returns on global socially responsible funds. Only in the case of

\footnotetext{
${ }^{17}$ We have considered other alternatives to measure the world market factor. All the models were also estimated with the market factor measured by the excess return on the FTSE All-World index. The results were similar to the ones reported in Table 4. In the case of the model with the two international factors and the model with the four factors we also considered the market factor measured by the series available in the Kenneth French webpage, the excess return on the international portfolio and the excess return on the US market, respectively. With these proxies the models do not seem to perform so well.
} 
Italian and US funds does this additional factor exhibit a statistically significant negative coefficient (at the 5\% level). This suggests that funds in these two countries are more exposed to growth stocks. According to this model, only Austrian funds continue to show a statistically significant negative alpha (at the $10 \%$ level).

When we include a world size factor in addition to a world market factor and a world value factor (estimates shown in Panel B), the explanatory power of the model increases for all countries. The coefficients on the size factor are positive and statistically significant for all country portfolios except for Italy and the Netherlands. This finding is consistent with previous studies that have also documented a small size bias in socially responsible funds. However, the style classification of most funds associates them with large cap investment strategies. The world value factor (measured in this case by a different proxy) continues to be statistically significant for Italian and US funds, both at the $1 \%$ level. It is also statistically significant for funds in UK and Austria (at the 5\% level). In all these cases the coefficients are negative, indicating exposure towards growth stocks. Although these findings are in line with previous studies, they are in contradiction with the style classification of some of the funds. In fact, some of the funds that are classified as pursuing value strategies are clearly biased towards growth stocks.

Based on the Wald test, we can reject the hypothesis of the two additional betas (for size and value) being equal to zero (at the 5\% level) for all the country portfolios except for the Netherlands. Furthermore, with few exceptions, the alphas are slightly lower. Once more, the alphas for the Austrian and the US fund portfolios are negative and statistically significant at the $5 \%$ and $1 \%$ levels, respectively.

Estimates reported in Panel C for the 4-factor model with the US value, size and momentum factors as proxies for world factors show similar results in terms of the 
statistical significance of the value and size factors. With this model, the portfolios of global socially responsible funds in Belgium and France exhibit a statistically significant positive coefficient (at the $10 \%$ level) on the value factor, while funds in Italy and in the US continue to present a statistically significant negative coefficient. The momentum factor seems less important than value and size in explaining excess returns on global socially responsible funds. This factor is statistically significant at the $1 \%$ level for the portfolio of French funds and at the $10 \%$ level for the portfolios of German, Italian and US funds. The hypothesis of the three additional betas being equal to zero is rejected (at the 5\% level) for all country portfolios except for the Dutch and the Austrian portfolios. Again, we observe that adding more factors leads to a slight decrease in alphas. Besides the Austrian and US fund portfolios, the French portfolio of funds also presents a statistically negative alpha (although in this case only at the $10 \%$ level).

\section{[Insert Table 4 here]}

Table 5 reports estimates for the same three multi-index models presented in Table 4, but now considering the excess returns on the FTSE4Good Global index as a proxy for the world market factor. Analyzing the corresponding panels we can conclude that the results are somewhat similar to the ones reported in Table 4 both in terms of performance estimates and of the statistical significance of the additional factors considered. With respect to style, the size factor emerges more clearly as the most important factor explaining the returns of global socially responsible funds. As in the single index model context, we observe lower estimates of betas and lower adjusted coefficient of determinations $\left(\mathrm{R}^{2}\right)$ for the multi-index models when a socially responsible index is used as the market benchmark. 


\section{[Insert Table 5 here]}

Results on the performance estimates for individual funds reported in Table 6 further support the previous analysis for the portfolios of funds. The inclusion of additional factors in the regressions generates slightly lower alphas. As before, when a socially responsible index is used as a benchmark, estimates of fund performance are more favourable than when a conventional benchmark is used.

\section{[Insert Table 6 here]}

\subsection{Home bias}

Although global funds are supposed to invest worldwide, a common finding in previous studies analyzing global conventional funds is that their holdings tend to be concentrated in the domestic market. This effect has also been documented on recent studies on socially responsible funds (Bauer et al., 2006; and Gregory and Whittaker, 2007). In order to control for this possibility, we run the alternative multi-index models with an additional local factor. This factor is measured by the return difference of the corresponding MSCI country index and the MSCI AC Global World index. ${ }^{18}$ Table 7 summarizes the main results of those models.

\section{[Insert Table 7 here]}

\footnotetext{
${ }^{18}$ As previously, we also rerun these models using the FTSE All-World index as the market benchmark. In this case the local factor is coherently measured by the return difference of the respective FTSE country index and the FTSE All-World index. Results are similar and thus not reported.
} 
The reported estimates show that, regardless of the multi-index used, the local factor is statistically significant in most of the portfolios of global socially responsible funds. Only for the portfolio of Austrian funds does this factor not appear as statistically significant in any of the multi-index models. The explanatory power of the models in general increases. Hence, one can conclude in favour of a significant home bias. Consistent with the models without the local factor, style patterns are clearly documented. The value factor has, for most country portfolios, a statistically significant negative coefficient. This is the case of the Italian and US portfolios of funds (for all the models), as well as for portfolios of UK, Austrian and Dutch funds in some models. With respect to the size factor, its coefficient is almost always positive and in many cases statistically significant (in particular for the portfolios of Austrian, German, UK and US funds). The momentum factor once more appears as significant mainly for the portfolio of French funds. ${ }^{19}$ In terms of performance estimates this set of models generate similar results, both at the country portfolio level as well as at the individual fund level (Table 8).

[Insert Table 8 here]

\subsection{Conditionals models}

In order to control for both time varying alphas and betas, the previous models are employed in their corresponding conditional specifications (according to equations [2] and [3]). Tables 9 and 10 summarize the results for the conditional multi-index models. ${ }^{20}$ In general, the explanatory power of the models increases. Regarding performance estimates, Austrian and US portfolios continue to exhibit statistically

\footnotetext{
${ }^{19}$ We have not performed regressions of the multi-index models with local factors with the socially responsible benchmark, as local socially responsible indices for the local factor are not available.

${ }^{20}$ Although not reported, we have also estimated the conditional single-index model and the conditional multi-index model with a local factor. In both cases the results are similar to those reported on table 9 .
} 
significant underperformance, whatever multi-index model used. At the country portfolio level, the results on the Wald tests show, in general, more evidence of timevarying betas than time-varying alphas. This time-variation is stronger for the conditional 3-factor model. The fact that there is scarce evidence of time-varying alphas might not be surprising, considering that the restrictions imposed upon funds that invest according to social criteria may contribute to a more stable performance over time. Also, the results on time-varying betas are not as strong as previous studies have shown (e.g., Bauer et al., 2006). ${ }^{21}$

Furthermore, the evidence concerning the investment style of the funds is similar to that obtained with the corresponding unconditional models.

[Insert Table 9 here]

[Insert Table 10 here]

\section{Conclusions}

Previous studies on the performance of socially responsible funds seem to suggest that it is possible "to do well while doing good" given that socially responsible funds show performance estimates comparable to those of conventional funds. However, these studies have been somewhat limited in terms of the type of funds analyzed (mostly domestic socially responsible funds) and of geographical scope. This study contributes to the literature by focusing in socially responsible funds that invest globally, by using a comprehensive set of performance metrics (traditional, multi-index and conditional alphas and betas) as well as by analyzing possible home bias of these fund managers. A sample composed of 46 funds from the US, Austria, Belgium, France,

\footnotetext{
${ }^{21}$ Whether these results reflect the fact that global socially responsible fund managers do not act upon economic conditions to the same extent as domestic fund managers or that the local public information variables are more appropriate is a debatable issue
} 
Germany, Italy, Netherlands and the UK is analyzed over the period from August 1996 to August 2008.

Using alternative specifications of the return generating process, we have examined fund performance relative to conventional and social responsible benchmark portfolios as well as the investment style of socially responsible funds. The results show that the performance of global socially responsible funds in European markets is comparable to the performance of conventional benchmarks and socially responsible benchmarks. US funds, and to a lesser extent, Austrian funds, though, show evidence of underperformance. These findings are robust to whatever performance model used (single and multiple index models as well as their conditional specifications). In the case of the US funds, these results contrast with previous studies that have typically found evidence of performance comparable to the benchmarks. The fact that the latest period of our sample includes a turbulent period in the financial markets, particularly in the US, might be a possible explanation for these results. The use of negative social screens (that leads to the exclusion of some activity sectors) could also help to explain this finding. Statman and Glushkov (2009), in a study for the US market, find that the return advantage obtained by investing in socially responsible firms is largely offset by the return disadvantage that comes from excluding stocks of 'shunned' firms. We have examined the disclosed information on the social screens of the underperforming funds but we could not conclude that they use more negative screens than the other funds.

An interesting result comes from the observation of evidence of time-varying betas, but not of time-varying alphas. The fact that socially responsible fund managers may be more constrained in terms of the security selection process may help to explain these results. It can be argued that firms with a good reputation concerning social responsibility could be more protected from stock price declines associated with bad 
times and thus socially responsible funds should present greater stability in terms of performance. This is an issue deserving further research.

With respect to investment style, we have found evidence that socially responsible funds are strongly exposed to small caps. This small size bias is consistent with previous studies and suggests that the social screening process implies that large firms are more likely to be excluded from the portfolios. However, these results uncover some misclassification issues in global socially responsible funds, as they are mostly labelled as large cap funds. Our results also indicate that socially responsible funds are tilted towards growth stocks. This tendency is more significant in the US and Italy. Again, the fund classifications are contradicted by the results, as funds that are categorised as value funds or even blend funds seem to be investing mainly in growth stocks.

We have also documented a significant home bias for global socially responsible funds. This finding is consistent with previous studies, and probably implies that investors in these funds do not benefit fully from the potential diversification effects that could arise from international investing.

In conclusion, the results of this research are of interest to investors that wish to incorporate social criteria in their investments decisions. Indeed, we found evidence that the majority of global socially responsible funds' performance is neutral compared to both conventional and socially responsible benchmarks. Additionally, our results are also relevant to financial regulators as we uncover potential style misclassification issues. 


\section{References}

Avramov D, Chordia, T. 2006. Predicting stock returns. Journal of Financial Economics 82 (2): 387-415.

Bauer R, Derwall J, Otten R. 2007. The ethical mutual fund performance debate: new evidence from Canada. Journal of Business Ethics 70(2): 111-124.

Bauer R, Koedijk K, Otten R. 2005. International evidence on ethical mutual fund performance and investment style. Journal of Banking \& Finance 29(7): 1751-1767.

Bauer R, Otten R, Rad AT. 2006. Ethical investing in Australia: Is there a financial penalty? Pacific-Basin Finance Journal 14(1): 33-48.

Bello ZY. 2005. Socially responsible investing and portfolio diversification. The Journal of Financial Research 28(1): 41-57.

Benson KL, Brailsford TJ, Humphrey JE. 2006. Do social responsible fund managers really invest differently? Journal of Business Ethics 65(4): 337-357.

Bernhardt I, Jung BS. 1979. The interpretation of least squares regression with interaction or polynomial terms. The Review of Economics and Statistics 61(3): 481483.

Breusch TS, Pagan AR. 1979. A simple test for heteroscedasticity and random coefficient variation. Econometrica, 47(5): 1287-1294.

Carhart MM. 1997. On persistence in mutual fund performance. Journal of Finance 52(1): $57-83$.

Christopherson JA, Ferson WE, Glassman DA. 1998. Conditioning manager alphas on information: another look at the persistence of performance. Review of Financial Studies 11(1): 111-142.

Christopherson JA, Ferson WE, Turner AL. 1999. Performance evaluation using conditional alphas and betas. Journal of Portfolio Management 26(1): 59-72. 
Chua CT, Lai S, Wu Y. 2008. Effective fair pricing of international mutual funds. Journal of Banking and Finance 32(11): 2307-2324.

Cortez MC, Silva F, Areal N. 2009. The performance of European socially responsible funds. Journal of Business Ethics 87(4): 573-588.

Cribari-Neto F. 2004. Asymptotic inference under heteroskedasticity of unknown form. Computational Statistics and Data Analysis 45(2): 215-233.

Elton EJ, Gruber MJ, Blake CR. 1996. The persistence of risk-adjusted mutual fund performance. Journal of Business 69(2): 133-157.

Fama EF, French KR. 1998. Value versus Growth: the international evidence. Journal of Finance 53(6): 1975-1999.

Fama EF, French KR. 1989. Business conditions and expected returns on stocks and bonds. Journal of Financial Economics 25(1): 23-49.

Ferson WE, Sarkissian S, Simin T. 2003. Is stock return predictability spurious? Journal of Investment Management 1(3): 1-10.

Ferson WE, Sarkissian S, Simin T. 2008. Asset pricing models with conditional betas and alphas: The effects of data snooping and spurious regression. Journal of Financial and Quantitative Analysis, 43(2): 331-354.

Ferson WE, Schadt RW. 1996. Measuring fund strategy and performance in changing economic conditions. Journal of Finance 51(2): 425-461.

Ferson WE, Warther VA. 1996. Evaluating fund performance in a dynamic market. Financial Analysts Journal 52(6): 20-28.

Goldreyer EF, Diltz JD. 1999. The performance of socially responsible mutual funds: incorporating sociopolitical information in portfolio selection. Managerial Finance 25(1): 23-36. 
Gregory A, Matatko J, Luther R. 1997. Ethical unit trust financial performance: small company effects and fund size effects. Journal of Business Finance \& Accounting 24(5): 705-725.

Gregory A, Whittaker J. 2007. Performance and performance persistence of 'ethical' unit trusts in the UK. Journal of Business Finance \& Accounting 34(7/8): 1327-1344.

Hamilton S, Jo H, Statman M. 1993. Doing well while doing good? The investment performance of socially responsible mutual funds. Financial Analysts Journal 49(6): 62-66.

Hill RP, Ainscough T, Shank T, Manullang D. 2007. Corporate social responsibility and social responsible investing: a global perspective. Journal of Business Ethics 70(2): $165-174$.

Jensen MC. 1968. The performance of mutual funds in the period 1945-1965. Joumal of Finance 23(2): 389-416.

Keim DB, Stambaugh RF. 1986. Predicting returns in the stock and bond markets. Journal of Financial Economics 17(2): 357-390.

Kempf A, Osthoff P. 2007. The Effect of Socially Responsible Investing on Portfolio Performance. European Financial Management 13(5): 908-922.

Kreander N, Gray RH, Power DM, Sinclair CD. 2002. The financial performance of European ethical funds 1996-1998. Journal of Accounting \& Finance 1: 3-22.

Louche C, Lydenberg, S. 2006. Socially responsible investment differences between Europe and United States. Working paper, Vlerick Leuven Gent Management School.

Luther RG, Matatko J, Corner DC. 1992. The investment performance of UK ethical unit trusts. Accounting, Auditing \& Accountability Journal 5(4): 57-70.

Luther RG, Matatko J. 1994. The performance of ethical unit trusts: choosing an appropriate benchmark. British Accounting Review 26(1): 77-89. 
Mallin CA, Saadouni B, Briston RJ. 1995. The financial performance of ethical investment funds. Journal of Business Finance \& Accounting 22(4): 483-496.

Newey WK, West KD. 1994. Automatic lag selection in covariance matrix estimation. The Review of Economic Studies 61(4): 631-653.

Renneborg L, Horst JT, Zhang C. 2008. The price of ethics and stakeholder governance: The performance of socially responsible mutual funds. Journal of Corporate Finance, 14(3): 302-322.

Reyes MG, Grieb T. 1998. The external performance of socially-responsible mutual funds. American Business Review 16(1): 1-7.

Rudd A. 1981. Social responsibility and portfolio performance. California Management Review 23(4): 55-61

Scholtens B. 2005. Style and performance of Dutch social responsible investment funds. Journal of Investing 14(1): 63-72.

Schröder M. 2004. The performance of socially responsible investments: investment funds and indices. Financial Markets and Portfolio Management 18(2): 122-142.

Schröder M. 2007. Is there a difference? The performance characteristics of SRI equity indices. Journal of Business Finance \& Accounting 34(1/2): 331-348.

Statman M. 2000. Socially responsible mutual funds. Financial Analysts Journal 56(3): 30-39.

Statman M. 2006. Socially responsible indexes: composition, performance and tracking error. Journal of Portfolio Management 32(3): 100-109.

Statman M, Glushkov D. 2009. The wages of social responsibility. Financial Analysts Journal 65(4): 33-46.

White H. 1980. A heteroskedasticity-consistent covariance matrix estimator and a direct test for heteroskedasticity. Econometrica 48(4): 817-838. 
Table 1 - Summary statistics of global SRI funds and global benchmarks

Summary statistics based on equally weighted portfolios of global SRI funds are presented for each country. Mean excess returns in percentage (considering monthly continuously compounded returns), standard deviation, minimum and maximum and the probability value of the Jarque-Bera test are reported for the period August 1996 to August 2008. The same statistics are also reported for both socially responsible and conventional world market indices: the FTSE4Good Global, the MSCI AC World, and the FTSE All-World index.

\begin{tabular}{|c|c|c|c|c|c|c|}
\hline Country & $\begin{array}{l}N^{0} \text { of } \\
\text { funds }\end{array}$ & $\begin{array}{l}\text { Mean excess } \\
\text { returns }(\%)\end{array}$ & $\begin{array}{c}\text { Standard } \\
\text { deviation }(\%)\end{array}$ & $\operatorname{Min}(\%)$ & $\operatorname{Max}(\%)$ & JB prob \\
\hline \multicolumn{7}{|l|}{ Euro countries } \\
\hline Austria & 9 & -0.080 & 4.543 & -12.984 & 10.758 & 0.003 \\
\hline Belgium & 6 & 0.293 & 4.591 & -13.702 & 8.673 & 0.000 \\
\hline France & 2 & -0.374 & 3.858 & -13.217 & 5.826 & 0.000 \\
\hline Germany & 4 & 0.041 & 5.357 & -17.182 & 24.541 & 0.000 \\
\hline Italy & 3 & -0.161 & 4.853 & -12.662 & 16.020 & 0.060 \\
\hline Netherlands & 5 & 0.283 & 4.909 & -13.592 & 11.430 & 0.005 \\
\hline FTSE4good Global $€$ & & 0.297 & 5.286 & -16.916 & 11.576 & 0.011 \\
\hline FTSE All-World $€$ & & 0.265 & 4.888 & -16.329 & 9.524 & 0.001 \\
\hline MSCI AC World $€$ & & 0.214 & 4.906 & -16.237 & 9.336 & 0.001 \\
\hline UK & 10 & -0.060 & 4.423 & -14.325 & 8.819 & 0.000 \\
\hline FTSE4good Global £ & & 0.112 & 4.951 & -18.729 & 9.855 & 0.000 \\
\hline FTSE All-World $£$ & & 0.065 & 4.639 & -18.149 & 9.767 & 0.000 \\
\hline MSCI AC World $£$ & & 0.029 & 4.649 & -18.046 & 9.590 & 0.000 \\
\hline US & 7 & -0.121 & 4.345 & -14.894 & 9.113 & 0.002 \\
\hline FTSE4good Global \$ & & 0.327 & 4.499 & -16.237 & 9.346 & 0.000 \\
\hline FTSE All-World \$ & & 0.279 & 4.170 & -15.647 & 8.483 & 0.000 \\
\hline MSCI AC World $\$$ & & 0.244 & 4.180 & -15.557 & 8.449 & 0.000 \\
\hline
\end{tabular}


Table 2 - Performance of equally weighted portfolios of global SRI funds considering unconditional single index models

Panel A of this table presents regression estimates for equally weighted portfolios of funds computed for each country using the single-index model with the MSCI AC World index as the benchmark. Alphas expressed in percentage, systematic risk (Beta) and the adjusted coefficient of determination $\left(\mathrm{R}^{2}\right)$ are reported. Regression residuals are tested using the Jarque-Bera test for normality, the White (1980) test for heteroscedasticity if the residuals are not normal, the Breusch and Pagan (1979) for heteroscedasticity if the residuals are normal and the Durbin-Watson test for autocorrelation. Standard errors are corrected, whenever appropriate, for the presence of heteroscedasticity using the correction of Cribari-Neto (2004) which performs better in smaller samples than White (1980), or for the presence of autocorrelation and heteroscedasticity using the procedure suggested by Newey and West (1994). Panel B reports the same type of estimates obtained using the single-index model with the FTSE4Good Global as the benchmark.

\begin{tabular}{llll}
\hline Country/Region & Alpha & Beta & $\mathbf{R}^{2}$ \\
\hline
\end{tabular}

Panel A - Conventional benchmark (MSCI AC World)

Euro countries

\begin{tabular}{|c|c|c|c|}
\hline Austria & $-0.260 *$ & $0.838^{* * * * *}$ & $81.9 \%$ \\
\hline Belgium & 0.104 & $0.880 * * *$ & $88.4 \%$ \\
\hline France & -0.045 & $0.750 * * *$ & $75.3 \%$ \\
\hline Germany & -0.124 & 0.770 **** & $49.3 \%$ \\
\hline Italy & -0.132 & 0.882 **** & $79.7 \%$ \\
\hline Netherlands & 0.088 & $0.907 * * *$ & $82.0 \%$ \\
\hline UK & -0.085 & $0.847 * * *$ & $79.1 \%$ \\
\hline US & $-0.358 * * *$ & $0.973 * * *$ & $87.5 \%$ \\
\hline \multicolumn{4}{|c|}{ Panel B - SRI benchmark (FTSE4Good Global) } \\
\hline \multicolumn{4}{|l|}{ Euro countries } \\
\hline Austria & $-0.304 *$ & $0.755 * * *$ & $77.0 \%$ \\
\hline Belgium & 0.053 & $0.808 * * *$ & $86.4 \%$ \\
\hline France & 0.040 & $0.696 * * *$ & $71.3 \%$ \\
\hline Germany & -0.167 & $0.697 * * *$ & $47.0 \%$ \\
\hline Italy & -0.142 & $0.825 * * *$ & $79.6 \%$ \\
\hline Netherlands & 0.033 & $0.841 * * *$ & $82.0 \%$ \\
\hline UK & -0.147 & $0.777 * * *$ & $75.5 \%$ \\
\hline US & $-0.410_{* * *}$ & $0.885 * * *$ & $83.8 \%$ \\
\hline
\end{tabular}

$* * *, * *, *$ Statistically significant at the $1 \%, 5 \%$ and $10 \%$ level, respectively. 
Table 3 - Performance estimates for individual global SRI funds considering single index models

This table shows the number of funds presenting positive and negative (+/-) alphas using single index models. Those which are statistically significant (at the 5\% percent level) are reported in brackets. Results on the two alternative specifications, considering either a conventional global market index (the MSCI AC World index) or a socially responsible index (the FTSE4Good Global index) as the global market benchmark are compared.

\begin{tabular}{lccc}
\hline Country/Region & $\begin{array}{c}\mathbf{N}^{\mathbf{0}} \text { of } \\
\text { funds }\end{array}$ & \multicolumn{2}{c}{ Alphas (+/-) } \\
\hline & & $\begin{array}{c}\text { Conventional benchmark } \\
\text { (MSCI AC World) }\end{array}$ & $\begin{array}{c}\text { SRI benchmark } \\
\text { (FTSE4Good Global) }\end{array}$ \\
Euro countries & & $4 / 5[1 / 2]$ & $6 / 3[1 / 1]$ \\
Austria & 9 & $3 / 3[0 / 1]$ & $2 / 4[0 / 0]$ \\
Belgium & 6 & $1 / 1[0 / 0]$ & $2 / 0[0 / 0]$ \\
France & 2 & $0 / 4[0 / 0]$ & $1 / 3[0 / 0]$ \\
Germany & 4 & $0 / 3[0 / 2]$ & $0 / 3[0 / 2]$ \\
Italy & 3 & $2 / 3[0 / 0]$ & $3 / 2[0 / 0]$ \\
Netherlands & 5 & $4 / 6[0 / 0]$ & $5 / 5[0 / 0]$ \\
UK & 10 & $0 / 7[0 / 2]$ & $1 / 6[0 / 2]$ \\
US & 7 & $14 / 32[1 / 7]$ & $20 / 26[1 / 5]$ \\
& 46 &
\end{tabular}


Table 4 - Performance of equally weighted portfolios of global SRI funds considering multi-index models (with a conventional market index as the world market benchmark)

This table shows the regressions estimates obtained considering alternative multi-index models. Panel A presents regressions estimates for equally weighted portfolios of funds computed for each country using the model with the two international factors of Fama and French (1998), a world market factor and a world value factor. This model is estimated for the period from August 1996 to December 2007, due to the availability of data on factors. Panel B reports regressions estimates for the three factor model which in addition to the world market return, also includes world value and size factors. Value is measured by the return difference of the MSCI AC World Value Growth indices and size is measured by the return difference of the MSCI AC World Small and Large indices. As some of the MSCI indices are only available since January 1997, the model is estimated for the period January 1997 to August 2008. Panel C shows the estimates for the four factor model following Carhart (1997). In addition to the world market factor, this model includes the US factors for value, size and momentum as proxies for world factors. This model is estimated over the full sample period August 1996 to August 2008. The world market factor in the each of the models is consistently measured by the excess return on the MSCI AC World index. Alphas expressed in percentage, beta coefficients, the adjusted $\mathrm{R}^{2}$ and the $\mathrm{p}$-value of the Wald test on the hypothesis of additional factors to the world market factor being equal to zero are reported. Regression residuals are tested using the Jarque-Bera test for normality, the White (1980) test for heteroscedasticity if the residuals are not normal, the Breusch and Pagan (1979) for heteroscedasticity if the residuals are normal and the Durbin-Watson test for autocorrelation. Standard errors are corrected, whenever appropriate, for the presence of heteroscedasticity using the correction of Cribari-Neto (2004), or for the presence of autocorrelation and heteroscedasticity using the procedure suggested by Newey and West (1994).

\begin{tabular}{|c|c|c|c|c|c|c|c|}
\hline Country/Region & alpha & $\begin{array}{c}\text { World } \\
\text { Mkt } \\
\end{array}$ & Value & Size & Mom & $\mathbf{R}^{2}$ & Wald \\
\hline \multicolumn{8}{|c|}{ Panel A - 2FF International factors (MSCI AC World) } \\
\hline \multicolumn{8}{|c|}{ Euro countries } \\
\hline Austria & $-0.264 *$ & $0.830 * * *$ & 0.009 & & & $80.8 \%$ & 0.846 \\
\hline Belgium & 0.116 & $0.869 * * *$ & 0.017 & & & $87.6 \%$ & 0.646 \\
\hline France & 0.016 & $0.704 * * *$ & 0.036 & & & $71.4 \%$ & 0.617 \\
\hline Germany & -0.102 & $0.754 * * *$ & 0.027 & & & $45.4 \%$ & 0.767 \\
\hline Italy & 0.065 & $0.828 * * *$ & $-0.276 * *$ & & & $83.1 \%$ & 0.000 \\
\hline Netherlands & 0.109 & $0.895 * * *$ & -0.026 & & & $81.0 \%$ & 0.607 \\
\hline UK & -0.089 & $0.820 * * *$ & -0.036 & & & $77.4 \%$ & 0.488 \\
\hline US & -0.241 & $0.984 * * *$ & $-0.216 * *$ & & & $88.8 \%$ & 0.000 \\
\hline \multicolumn{8}{|c|}{ Panel B - World 3-Factor (MSCI AC World) } \\
\hline \multicolumn{8}{|c|}{ Euro countries } \\
\hline Austria & $-0.259 * *$ & $0.861^{* * *}$ & $-0.241 * *$ & $0.288 * * *$ & & $84.3 \%$ & 0.000 \\
\hline Belgium & 0.060 & $0.903^{* * *}$ & 0.057 & $0.198^{* * *}$ & & $89.4 \%$ & 0.002 \\
\hline France & -0.210 & $0.744 * * *$ & 0.238 & $0.247 * *$ & & $77.1 \%$ & 0.015 \\
\hline Germany & -0.263 & $0.850 * * *$ & 0.238 & $0.739 *$ & & $58.8 \%$ & 0.000 \\
\hline Italy & -0.084 & $0.860 * * *$ & $-0.806 * * *$ & 0.186 & & $85.6 \%$ & 0.000 \\
\hline Netherlands & 0.063 & $0.917 * * *$ & -0.172 & 0.087 & & $83.5 \%$ & 0.234 \\
\hline UK & -0.166 & $0.876 * * *$ & $-0.279 * *$ & $0.560 * * * *$ & & $87.9 \%$ & 0.000 \\
\hline US & $-0.336 * * *$ & $0.961 * * *$ & $-0.482 * * *$ & $0.200 * * *$ & & $90.4 \%$ & 0.000 \\
\hline \multicolumn{8}{|c|}{ Panel C - World Carhart 4-F (MSCI AC World) } \\
\hline \multicolumn{8}{|c|}{ Euro countries } \\
\hline Austria & $-0.274 * *$ & $0.852 * * *$ & 0.006 & $0.099 * * *$ & -0.023 & $82.5 \%$ & 0.051 \\
\hline Belgium & 0.015 & $0.942 * * *$ & $0.065 *$ & 0.045 & 0.031 & $88.8 \%$ & 0.037 \\
\hline France & $-0.345 *$ & $0.935 * * *$ & $0.126 *$ & 0.027 & $0.169^{* * * *}$ & $81.2 \%$ & 0.000 \\
\hline Germany & -0.151 & $0.799 * * *$ & 0.013 & $0.294 * * * *$ & $-0.083 *$ & $54.6 \%$ & 0.000 \\
\hline Italy & -0.112 & $0.804 * * *$ & $-0.263 * * *$ & 0.120 & $0.079 *$ & $87.4 \%$ & 0.000 \\
\hline Netherlands & 0.034 & $0.943 * * *$ & 0.030 & 0.058 & 0.014 & $82.1 \%$ & 0.332 \\
\hline UK & -0.136 & $0.853^{* * *}$ & -0.014 & $0.245^{* * *}$ & -0.021 & $84.8 \%$ & 0.000 \\
\hline US & $-0.375 * * *$ & $0.936 * * *$ & $-0.089 * *$ & 0.135 **** & $0.036 *$ & $90.7 \%$ & 0.000 \\
\hline
\end{tabular}

***,**,* Statistically significant at the $1 \%, 5 \%$ and $10 \%$ level, respectively. 


\section{Table 5 - Performance of equally weighted portfolios of global SRI funds considering multi-index models (with a SRI market index as the world market benchmark)}

This table shows the regressions estimates obtained considering alternative multi-index models. Panel A presents regressions estimates for equally weighted portfolios of funds computed for each country using the model with the two international factors of Fama and French (1998), a world market factor and a world value factor. This model is estimated for the period from August 1996 to December 2007, due to the availability of data on factors. Panel B reports regressions estimates for the three factor model which in addition to the world market return, also includes world value and size factors. Value is measured by the return difference of the MSCI AC World Value and Growth indices and size is measured by the return difference of the MSCI AC World Small and Large indices. As some of the MSCI indices are only available since January 1997, the model is estimated for the period January 1997 to August 2008. Panel C shows the estimates for the four factor model following Carhart (1997). In addition to the world market factor, this model includes the US factors for value, size and momentum as proxies for world factors. This model is estimated over the full sample period August 1996 to August 2008. The world market factor in the each of the models is consistently measured by the excess return on the FTSE4Good Global index. Alphas expressed in percentage, beta coefficients, the adjusted $\mathrm{R}^{2}$ and the p-value of the Wald test on the hypothesis of additional factors to the world market factor being equal to zero are reported. Regression residuals are tested using the Jarque-Bera test for normality, the White (1980) test for heteroscedasticity if the residuals are not normal, the Breusch and Pagan (1979) for heteroscedasticity if the residuals are normal and the Durbin-Watson test for autocorrelation. Standard errors are corrected, whenever appropriate, for the presence of heteroscedasticity using the correction of Cribari-Neto (2004), or for the presence of autocorrelation and heteroscedasticity using the procedure suggested by Newey and West (1994).

\begin{tabular}{|c|c|c|c|c|c|c|c|}
\hline Country/Region & alpha & $\begin{array}{c}\text { World } \\
\text { Mkt } \\
\end{array}$ & Value & Size & Mom & $\mathbf{R}^{2}$ & Wald \\
\hline \multicolumn{8}{|c|}{ Panel A - 2FF International factors (FTSE4Good Global) } \\
\hline \multicolumn{8}{|c|}{ Euro countries } \\
\hline Austria & -0.309 & $0.750 * * *$ & 0.018 & & & $76.3 \%$ & 0.722 \\
\hline Belgium & 0.056 & $0.803 * * *$ & 0.035 & & & $86.1 \%$ & 0.371 \\
\hline France & 0.124 & $0.650 * * *$ & 0.021 & & & $67.1 \%$ & 0.785 \\
\hline Germany & -0.146 & $0.685 * * *$ & 0.038 & & & $43.3 \%$ & 0.689 \\
\hline Italy & 0.046 & $0.774 * * *$ & $-0.258 * *$ & & & $82.5 \%$ & 0.000 \\
\hline Netherlands & 0.038 & $0.838 * * *$ & -0.001 & & & $81.6 \%$ & 0.980 \\
\hline UK & -0.156 & $0.755^{* * *}$ & -0.029 & & & $74.4 \%$ & 0.600 \\
\hline US & $-0.315 *$ & $0.887 * * *$ & -0.160 & & & $84.2 \%$ & 0.003 \\
\hline \multicolumn{8}{|c|}{ Panel B - World 3-Factor (FTSE4Good Global) } \\
\hline \multicolumn{8}{|c|}{ Euro countries } \\
\hline Austria & $-0.288 * *$ & $0.798 * * *$ & -0.188 & $0.381 * * *$ & & $80.8 \%$ & 0.000 \\
\hline Belgium & 0.025 & $0.852 * * *$ & 0.121 & $0.303 * * *$ & & $88.8 \%$ & 0.000 \\
\hline France & -0.165 & $0.696 * * *$ & 0.182 & $0.352 * * *$ & & $74.3 \%$ & 0.003 \\
\hline Germany & -0.298 & $0.808 * * *$ & 0.302 & $0.842 * * *$ & & $59.3 \%$ & 0.000 \\
\hline Italy & -0.123 & $0.815^{* * *}$ & -0.742 & $0.288 *$ & & $85.5 \%$ & 0.000 \\
\hline Netherlands & 0.026 & $0.868 * * *$ & $-0.105 * * *$ & $0.195 * *$ & & $83.6 \%$ & 0.039 \\
\hline UK & -0.206 & $0.830_{* * *}^{*}$ & $-0.213 *$ & $0.671 * * *$ & & $87.1 \%$ & 0.000 \\
\hline US & $-0.369^{* * *}$ & 0.896 *** & $-0.418^{* * * *}$ & $0.319^{* * *}$ & & $87.9 \%$ & 0.000 \\
\hline \multicolumn{8}{|c|}{ Panel C - World Carhart 4-F (FTSE4Good Global) } \\
\hline \multicolumn{8}{|c|}{ Euro countries } \\
\hline Austria & $-0.305 * *$ & $0.760 * * *$ & -0.002 & $0.108 * * *$ & -0.036 & $77.7 \%$ & 0.061 \\
\hline Belgium & -0.046 & $0.872 * * *$ & $0.076 *$ & $0.059 *$ & 0.024 & $87.0 \%$ & 0.032 \\
\hline France & -0.236 & 0.909 *** & 0.105 & 0.011 & $0.218 * * *$ & $78.4 \%$ & 0.000 \\
\hline Germany & -0.191 & 0.727 *** & 0.014 & $0.304 * * *$ & $-0.091 *$ & $52.6 \%$ & 0.000 \\
\hline Italy & -0.131 & $0.758 * * *$ & $-0.250 * * *$ & 0.126 & $0.078 *$ & $87.0 \%$ & 0.000 \\
\hline Netherlands & -0.040 & $0.889 * * *$ & 0.051 & $0.074 *$ & 0.010 & $82.2 \%$ & 0.156 \\
\hline UK & -0.186 & $0.776 * * *$ & -0.021 & $0.254 * * *$ & -0.033 & $81.5 \%$ & 0.000 \\
\hline US & $-0.455 * * *$ & $0.862 * * *$ & -0.050 & $0.175 * * *$ & 0.035 & $87.4 \%$ & 0.000 \\
\hline
\end{tabular}

$* * *, * *, *$ Statistically significant at the $1 \%, 5 \%$ and $10 \%$ level, respectively. 


\section{Table 6 - Performance estimates for individual global SRI funds considering multi- index models}

This table shows the number of funds presenting positive and negative (+/-) alphas using multi-index models. Those which are statistically significant (at the 5\% percent level) are reported in brackets. Three alternative multi-index are considered. Panel A summarizes the results of the model with the two international factors of Fama and French (1998), a world market factor and a world value factor. This model is estimated for the period from August 1996 to December 2007, due to the availability of data on factors. Panel B refers to the three factor model which in addition to the world market return, also includes world value and size factors. Value is measured by the return difference of the MSCI AC World Value and Growth indices and size is measured by the return difference of the MSCI AC World Small and Large indices. As some of the MSCI indices are only available since January 1997, the model is estimated for the period January 1997 to August 2008. Panel C shows the results for the four factor model following Carhart (1997). In addition to the world market factor, this model includes the US factors for value, size and momentum as proxies for world factors. This model is estimated over the full sample period August 1996 to August 2008. Results on the two alternative specifications, considering either a conventional global market index (the MSCI AC World index) or a socially responsible index (the FTSE4Good Global index) as the global market benchmark are compared.

\begin{tabular}{|c|c|c|c|}
\hline \multirow{3}{*}{$\begin{array}{l}\text { Country/Region } \\
\text { Panel A - 2FF International factors } \\
\text { Euro countries }\end{array}$} & \multirow{2}{*}{$\begin{array}{l}N^{0} \text { of } \\
\text { funds }\end{array}$} & \multicolumn{2}{|c|}{ Alphas (+/-) } \\
\hline & & $\begin{array}{l}\text { Conventional benchmark } \\
\text { (MSCI AC World) }\end{array}$ & $\begin{array}{c}\text { SRI benchmark } \\
\text { (FTSE4Good Global) }\end{array}$ \\
\hline & & & \\
\hline Austria & 9 & $3 / 6[0 / 2]$ & $6 / 3[0 / 1]$ \\
\hline Belgium & 6 & $3 / 3[0 / 1]$ & $3 / 3[0 / 1]$ \\
\hline France & 2 & $1 / 1[0 / 0]$ & $2 / 0[0 / 0]$ \\
\hline Germany & 4 & $0 / 4[0 / 1]$ & $1 / 3[0 / 0]$ \\
\hline Italy & 3 & $1 / 2[0 / 2]$ & $1 / 2[0 / 1]$ \\
\hline Netherlands & 5 & $2 / 3[0 / 0]$ & $2 / 3[0 / 0]$ \\
\hline UK & 10 & $5 / 5[0 / 0]$ & $4 / 6[0 / 0]$ \\
\hline \multirow[t]{2}{*}{ US } & 7 & $1 / 6[0 / 2]$ & $1 / 6[0 / 2]$ \\
\hline & & $16 / 30[0 / 8]$ & $20 / 26[0 / 5]$ \\
\hline \multicolumn{4}{|l|}{ Panel B - World 3-Factor } \\
\hline \multicolumn{4}{|l|}{ Euro countries } \\
\hline Austria & 9 & $2 / 7[0 / 2]$ & $4 / 5[1 / 2]$ \\
\hline Belgium & 6 & $2 / 4[0 / 1]$ & $2 / 4[0 / 0]$ \\
\hline France & 2 & $1 / 1[0 / 0]$ & $1 / 1[0 / 0]$ \\
\hline Germany & 4 & $0 / 4[0 / 0]$ & $1 / 3[0 / 0]$ \\
\hline Italy & 3 & $0 / 3[0 / 2]$ & $0 / 3[0 / 2]$ \\
\hline Netherlands & 5 & $1 / 4[0 / 0]$ & $2 / 3[0 / 0]$ \\
\hline UK & 10 & $3 / 7[0 / 2]$ & $3 / 7[0 / 1]$ \\
\hline \multirow[t]{2}{*}{ US } & 7 & $0 / 7[0 / 5]$ & $1 / 6[0 / 4]$ \\
\hline & & $9 / 37[0 / 12]$ & $14 / 32[1 / 9]$ \\
\hline \multicolumn{4}{|l|}{ Panel C - World Carhart 4-Factor } \\
\hline \multicolumn{4}{|l|}{ Euro countries } \\
\hline Austria & 9 & $1 / 8[0 / 2]$ & $3 / 6[0 / 1]$ \\
\hline Belgium & 6 & $2 / 4[0 / 2]$ & $2 / 4[0 / 1]$ \\
\hline France & 2 & $0 / 2[0 / 1]$ & $0 / 2[0 / 1]$ \\
\hline Germany & 4 & $0 / 4[0 / 2]$ & $0 / 4[0 / 1]$ \\
\hline Italy & 3 & $0 / 3[0 / 2]$ & $0 / 3[0 / 2]$ \\
\hline Netherlands & 5 & $1 / 4[0 / 0]$ & $1 / 4[0 / 0]$ \\
\hline UK & 10 & $2 / 8[0 / 1]$ & $3 / 7[0 / 0]$ \\
\hline \multirow[t]{2}{*}{ US } & 7 & $1 / 6[0 / 5]$ & $1 / 6[0 / 4]$ \\
\hline & & $7 / 39[0 / 15]$ & $10 / 36[0 / 10]$ \\
\hline
\end{tabular}




\section{Table 7 - Performance of equally weighted portfolios of global SRI funds considering multi-index models that control for home bias}

This table shows the regressions estimates obtained considering the same alternative multi-index models of table 4 with an additional local factor in order to control for the possibility of a home bias in fund investments strategies. Panel A presents regressions estimates for equally weighted portfolios of funds computed for each country using the model with the two international factors of Fama and French (1998), a world market factor and a world value factor plus the local factor. This model is estimated for the period from August 1996 to December 2007, due to the availability of data on factors. Panel B reports regressions estimates for the model with the world market return, the world value and size factors and now also a local factor. Value is measured by the return difference of the MSCI AC World Value and Growth indices and size is measured by the return difference of the MSCI AC World Small and Large indices. As some of the MSCI indices are only available since January 1997, the model is estimated for the period January 1997 to August 2008. Panel C shows the estimates for the factor model following Carhart (1997). In addition to the world market factor, this model includes the US factors for value, size and momentum as proxies for world factors and now also a local factor. This model is estimated over the full sample period August 1996 to August 2008. The world market factor in each of the models is consistently measured by the excess return on the MSCI AC World index. This also happens for local factor return which is measured by the return difference of the respective MSCI country index and the MSCI AC World index. Alphas expressed in percentage, betas, the adjusted $\mathrm{R}^{2}$ and the $\mathrm{p}$-value of the Wald test on the hypothesis of additional factors to the world market factor being equal to zero are reported. Regression residuals are tested using the Jarque-Bera test for normality, the White (1980) test for heteroscedasticity if the residuals are not normal, the Breusch and Pagan (1979) for heteroscedasticity if the residuals are normal and the Durbin-Watson test for autocorrelation. Standard errors are corrected, whenever appropriate, for the presence of heteroscedasticity using the correction of Cribari-Neto (2004), or for the presence of autocorrelation and heteroscedasticity using the procedure suggested by Newey and West (1994).

\begin{tabular}{|c|c|c|c|c|c|c|c|c|}
\hline Country/Region & alpha & $\begin{array}{l}\text { World } \\
\text { Mkt }\end{array}$ & Value & Size & Mom & $\begin{array}{l}\text { Local } \\
\text { Mkt }\end{array}$ & $\mathbf{R}^{2}$ & Wald \\
\hline \multicolumn{9}{|c|}{$\begin{array}{l}\text { Panel A - } 2 \text { FF International factors \& a local factor } \\
\text { Euro countries }\end{array}$} \\
\hline Austria & $-0.277 *$ & $0.844 * * * *$ & -0.010 & & & 0.047 & $80.9 \%$ & 0.517 \\
\hline Belgium & 0.108 & 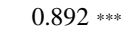 & -0.017 & & & 0.106 & $88.2 \%$ & 0.016 \\
\hline France & 0.050 & $0.681 *$ *** & -0.034 & & & $0.218^{* *}$ & $72.5 \%$ & 0.111 \\
\hline Germany & -0.125 & $0.6977^{* * *}$ & -0.014 & & & $0.278^{* *}$ & $48.7 \%$ & 0.010 \\
\hline Italy & -0.019 & $0.859^{* * * *}$ & $-0.302 * * * *$ & & & $0.240^{* *}$ & $86.8 \%$ & 0.000 \\
\hline Netherlands & 0.113 & 0.883 **** & -0.084 & & & $0.276_{* * *}$ & $83.8 \%$ & 0.000 \\
\hline UK & -0.093 & $0.855 * * *$ & -0.057 & & & 0.142 & $77.6 \%$ & 0.271 \\
\hline US & $-0.231 * *$ & $0.980 * * * *$ & $-0.217 * * * *$ & & & $-0.487 * * *$ & $91.5 \%$ & 0.000 \\
\hline \multicolumn{9}{|c|}{ Panel B - World 3-Factor \& a local factor } \\
\hline \multicolumn{9}{|c|}{ Euro countries } \\
\hline Austria & $-0.273 * *$ & $0.874 * * *$ & $-0.292 * *$ & $0.268 * * *$ & & 0.052 & $84.4 \%$ & 0.000 \\
\hline Belgium & 0.056 & $0.926 * * * *$ & -0.023 & $0.214 * * * *$ & & $0.106 *$ & $90.1 \%$ & 0.000 \\
\hline France & -0.254 & $0.725^{* * * *}$ & 0.215 & $0.273 *$ & & $0.244 * *$ & $78.8 \%$ & 0.001 \\
\hline Germany & -0.296 & $0.808 * * *$ & 0.229 & $0.705^{* * *}$ & & $0.232 * * *$ & $60.9 \%$ & 0.000 \\
\hline Italy & -0.137 & $0.881 * * *$ & -0.796 ***** & 0.153 & & $0.187^{* *}$ & $87.8 \%$ & 0.000 \\
\hline Netherlands & 0.069 & $0.906 * * *$ & $-0.322 * * *$ & 0.068 & & $0.278^{* * *}$ & $86.3 \%$ & 0.000 \\
\hline UK & -0.161 & $0.948_{* * *}$ & $-0.393^{* * * *}$ & $0.607 * * *$ & & 0.300 **** & $89.1 \%$ & 0.000 \\
\hline US & $-0.321^{* * * *}$ & 0.944 **** & $-0.469^{* * * *}$ & $0.099 *$ & & $-0.392_{* * *}$ & $91.9 \%$ & 0.000 \\
\hline \multicolumn{9}{|c|}{ Panel C - World Carhart 4-Factor \& a local factor } \\
\hline \multicolumn{9}{|l|}{ Euro countries } \\
\hline Austria & $-0.264 *$ & 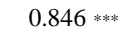 & -0.034 & $0.093 * *$ & -0.033 & 0.067 & $82.7 \%$ & 0.037 \\
\hline Belgium & 0.043 & 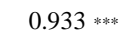 & 0.023 & 0.041 & 0.023 & 0.082 & $89.1 \%$ & 0.009 \\
\hline France & $-0.322 *$ & 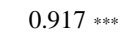 & 0.110 & 0.006 & 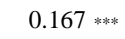 & 0.095 & $81.2 \%$ & 0.000 \\
\hline Germany & -0.126 & $0.731^{\text {**** }}$ & -0.035 & $0.238^{* * * *}$ & $-0.086 *$ & $0.180 *$ & $55.5 \%$ & 0.000 \\
\hline Italy & -0.130 & 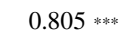 & -0.281 **** & 0.079 & $0.076 *$ & $0.1677^{* *}$ & $88.9 \%$ & 0.000 \\
\hline Netherlands & 0.090 & 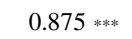 & -0.068 & 0.018 & 0.007 & $0.276 * * *$ & $84.4 \%$ & 0.000 \\
\hline UK & -0.122 & $0.884 *$ *** & -0.069 & $0.246^{* * * *}$ & -0.025 & $0.246^{* *}$ & $85.6 \%$ & 0.000 \\
\hline US & $-0.296 * * *$ & $0.908_{* * * *}$ & $-0.140 * * *$ & $0.079 * *$ & 0.013 & $-0.377_{* * *}$ & $92.0 \%$ & 0.000 \\
\hline
\end{tabular}

$* * *, * *, *$ Statistically significant at the $1 \%, 5 \%$ and $10 \%$ level, respectively. 
Table 8 - Performance estimates for individual global SRI funds considering multiindex models that control for home bias

This table shows the number of funds presenting positive and negative (+/-) alphas using multi-index models described in table 7. Those which are statistically significant (at the 5\% percent level) are reported in brackets. Panel A summarizes the results of the model with the two international factors of Fama and French (1998), a world market factor and a world value factor plus the local factor. This model is estimated for the period from August 1996 to December 2007, due to the availability of data on factors. Panel B reports results for the model with the world market return, the world value and size factors and also a local factor. Value is measured by the return difference of the MSCI AC World Value and Growth indices and size is measured by the return difference of the MSCI AC World Small and Large indices. As some of the MSCI indices are only available since January 1997, the model is estimated for the period January 1997 to August 2008. Panel C shows the results for the factor model following Carhart (1997). In addition to the world market factor, this model includes the US factors for value, size and momentum as proxies for world factors and also a local factor. This model is estimated over the full sample period August 1996 to August 2008. In all these models the local factor is measured by the return difference of the corresponding MSCI country index and the MSCI AC Global index.

\begin{tabular}{lcc}
\hline Country/Region & $\begin{array}{c}\mathbf{N}^{\mathbf{0}} \text { of } \\
\text { funds }\end{array}$ & Alphas (+/-) \\
\hline Panel A - 2FF International factors \& a local factor & & $\begin{array}{c}\text { Conventional benchmark } \\
\text { (MSCI AC World) }\end{array}$ \\
Euro countries & & \\
$\quad$ Austria & 9 & $0 / 9[0 / 2]$ \\
Belgium & 6 & $3 / 3[0 / 1]$ \\
France & 2 & $1 / 1[0 / 0]$ \\
Germany & 4 & $0 / 4[0 / 1]$ \\
Italy & 3 & $0 / 3[0 / 2]$ \\
Netherlands & 5 & $2 / 3[0 / 0]$ \\
UK & 10 & $5 / 5[0 / 0]$ \\
US & 7 & $2 / 5[0 / 1]$ \\
& & $13 / 33[0 / 7]$ \\
\hline
\end{tabular}

Panel B - World 3-Factor \& a local factor

Euro countries

$\begin{array}{lcc}\text { Austria } & 9 & 1 / 8[0 / 2] \\ \text { Belgium } & 6 & 2 / 4[0 / 1] \\ \text { France } & 2 & 0 / 2[0 / 0] \\ \text { Germany } & 4 & 0 / 4[0 / 1] \\ \text { Italy } & 3 & 0 / 3[0 / 2] \\ \text { Netherlands } & 5 & 1 / 4[0 / 0] \\ \text { UK } & 10 & 3 / 7[0 / 2] \\ \text { US } & 7 & 1 / 6[0 / 4] \\ & & 8 / 38[0 / 12]\end{array}$

Panel C - World Carhart 4-Factor \& a local factor

Euro countries

\begin{tabular}{lcc} 
Austria & 9 & $1 / 8[0 / 2]$ \\
Belgium & 6 & $2 / 4[0 / 2]$ \\
France & 2 & $0 / 2[0 / 1]$ \\
Germany & 4 & $0 / 4[0 / 2]$ \\
Italy & 3 & $0 / 3[0 / 2]$ \\
Netherlands & 5 & $2 / 3[0 / 0]$ \\
UK & 10 & $2 / 8[0 / 1]$ \\
US & 7 & $1 / 6[0 / 3]$ \\
& & $8 / 38[0 / 13]$ \\
\hline
\end{tabular}




\section{Table 9 - Performance of equally weighted portfolios of global SRI funds considering conditional models}

This table shows the results of conditional multi-index models. The short term rate and the dividend yield are used as conditioning information variables. Panel A presents results for equally weighted portfolios of funds computed using the model with the two international factors of Fama and French (1998), a world market factor and a world value factor. This model is estimated for the period from August 1996 to December 2007, due to the availability of data on factors. Panel B reports estimates for the model with the world market return, the world value and size factors. Value is measured by the return difference of the MSCI AC World Value and Growth indices and size is measured by the return difference of the MSCI AC World Small and Large indices. As some of these indices are only available since January 1997, the model is estimated for the period January 1997 to August 2008. Panel C shows the estimates for the factor model following Carhart (1997). In addition to the world market factor, it includes the US factors for value, size and momentum as proxies for world factors. This model is estimated over the full sample period August 1996 to August 2008. The world market factor is consistently measured by the excess return on the MSCI AC World index. In each of the models we add the cross products between the performance measure and the information variables (time-varying alphas) as well as the cross products between the world factors and the information variables (timevarying betas). Average alphas expressed in percentage, the adjusted $\mathrm{R}^{2}$ and the p-value of the Wald test are reported. Wald 1 tests the hypothesis that the additional factors resulting from both time-varying alphas and betas are jointly equal to zero. Wald 2 tests the hypothesis that the additional factors resulting from time-varying alphas are equal to zero. Wald 3 tests the hypothesis that the additional factors resulting from time-varying betas are equal to zero. The number of funds for which the Wald tests are statistically significant (at the 5\% level) are reported in brackets. Regression residuals are tested using the Jarque-Bera test for normality, the White (1980) test for heteroscedasticity if the residuals are not normal, the Breusch and Pagan (1979) for heteroscedasticity if the residuals are normal and the Durbin-Watson test for autocorrelation. Standard errors are corrected, whenever appropriate, for the presence of heteroscedasticity using the correction of Cribari-Neto (2004), or for the presence of autocorrelation and heteroscedasticity using the procedure suggested by Newey and West (1994).

\begin{tabular}{|c|c|c|c|c|c|c|c|}
\hline Country/Region & alpha & $\mathbf{R}^{2}$ & Wald 1 & Wald & & Wald 3 & $\begin{array}{l}\mathbf{N}^{\circ} \text { of } \\
\text { Funds }\end{array}$ \\
\hline \multicolumn{8}{|c|}{ Panel A - Conditional 2-Factor Model (MSCI AC Global) } \\
\hline \multicolumn{8}{|c|}{ Euro countries } \\
\hline Austria & $-0.247 *$ & $82.1 \%$ & $0.023[4]$ & 0.047 & {$[1]$} & $0.082[3]$ & 9 \\
\hline Belgium & 0.082 & $88.9 \%$ & $0.002[3]$ & 0.001 & {$[1]$} & $0.092[3]$ & 6 \\
\hline France & 0.002 & $77.5 \%$ & $0.000[1]$ & 0.021 & {$[1]$} & $0.001[2]$ & 2 \\
\hline Germany & 0.024 & $54.2 \%$ & $0.000[3]$ & 0.006 & {$[2]$} & $0.000[3]$ & 4 \\
\hline Italy & -0.089 & $86.4 \%$ & $0.000[2]$ & 0.056 & {$[0]$} & $0.000[2]$ & 3 \\
\hline Netherlands & 0.111 & $83.1 \%$ & $0.002[1]$ & 0.004 & {$[1]$} & $0.014[1]$ & 5 \\
\hline UK & -0.089 & $81.7 \%$ & $0.000[4]$ & 0.002 & {$[3]$} & $0.000[4]$ & 10 \\
\hline \multirow[t]{2}{*}{ US } & $-0.275 * *$ & $90.1 \%$ & $0.001[3]$ & 0.034 & {$[2]$} & $0.003[3]$ & 7 \\
\hline & & & {$[21]$} & & [11] & [21] & 46 \\
\hline \multicolumn{8}{|c|}{ Panel B - Conditional 3-Factor Model (MSCI AC Global) } \\
\hline \multicolumn{8}{|l|}{ Euro countries } \\
\hline Austria & $-0.238 * *$ & $87.3 \%$ & $0.000[8]$ & 0.018 & {$[2]$} & $0.000[8]$ & 9 \\
\hline Belgium & 0.068 & $90.8 \%$ & 0.001 & 0.006 & {$[0]$} & 0.003 & 6 \\
\hline France & -0.170 & $77.8 \%$ & 0.225 & 0.287 & {$[0]$} & 0.216 & 2 \\
\hline Germany & -0.222 & $67.1 \%$ & $0.000 \quad[2]$ & 0.062 & [1] & $0.000 \quad[2]$ & 4 \\
\hline Italy & 0.055 & $87.3 \%$ & 0.003 [2] & 0.137 & {$[0]$} & $0.007 \quad[2]$ & 3 \\
\hline Netherlands & 0.102 & $85.4 \%$ & $0.002[2]$ & 0.006 & {$[0]$} & $0.006[2]$ & 5 \\
\hline UK & -0.158 & $90.5 \%$ & 0.000 & 0.001 & {$[5]$} & $0.000 \quad[7]$ & 10 \\
\hline \multirow[t]{2}{*}{ US } & $-0.268 * *$ & $91.0 \%$ & $0.042[2]$ & 0.093 & {$[1]$} & $0.193[1]$ & 7 \\
\hline & & & [26] & & [9] & [25] & 46 \\
\hline \multicolumn{8}{|c|}{ Panel C - Conditional 4-Factor Model (MSCI AC Global) } \\
\hline \multicolumn{8}{|c|}{ Euro countries } \\
\hline Austria & $-0.274 * *$ & $83.4 \%$ & $0.070[1]$ & 0.012 & [1] & $0.119[1]$ & 9 \\
\hline Belgium & 0.041 & $89.8 \%$ & $0.011[2]$ & 0.003 & {$[1]$} & $0.064[1]$ & 6 \\
\hline France & -0.187 & $81.5 \%$ & $0.360[0]$ & 0.246 & [0] & $0.263[0]$ & 2 \\
\hline Germany & 0.051 & $58.1 \%$ & $0.024[2]$ & 0.014 & [1] & $0.163[1]$ & 4 \\
\hline Italy & -0.042 & $89.0 \%$ & $0.003[1]$ & 0.069 & {$[0]$} & $0.007[1]$ & 3 \\
\hline Netherlands & 0.059 & $83.5 \%$ & $0.023[1]$ & 0.007 & {$[0]$} & $0.062[0]$ & 5 \\
\hline UK & -0.047 & $86.9 \%$ & $0.001[4]$ & 0.010 & [3] & $0.007[4]$ & 10 \\
\hline \multirow[t]{2}{*}{ US } & $-0.359 * * *$ & $91.1 \%$ & $0.082[1]$ & 0.054 & {$[2]$} & $0.271[1]$ & 7 \\
\hline & & & {$[12]$} & & {$[8]$} & [9] & 46 \\
\hline
\end{tabular}

$* * *, * *, *$ Statistically significant at the $1 \%, 5 \%$ and $10 \%$ level, respectively. 


\section{Table 10 - Performance estimates for individual global SRI funds considering conditional models}

This table shows the number of funds presenting positive and negative (+/-) alphas using conditional multi-index models. Those which are statistically significant (at the 5\% percent level) are reported in brackets. Panel A summarizes the results of the model with the two international factors of Fama and French (1998), a world market factor and a world value factor. This model is estimated for the period from August 1996 to December 2007, due to the availability of data on factors. Panel B reports results for the model with the world market return, the world value and size factors. Value is measured by the return difference of the MSCI AC World Value and Growth indices and size is measured by the return difference of the MSCI AC World Small and Large indices. As some of the MSCI indices are only available since January 1997, the model is estimated for the period January 1997 to August 2008. Panel C shows the results for the factor model following Carhart (1997). In addition to the world market factor, this model includes the US factors for value, size and momentum as proxies for world factors. This model is estimated over the full sample period August 1996 to August 2008.

\begin{tabular}{lrc}
\hline Country/Region & $\begin{array}{c}\mathbf{N}^{\mathbf{0}} \text { of } \\
\text { funds }\end{array}$ & Alphas (+/-) \\
\hline Panel A - Conditional 2FF International factors & & $\begin{array}{c}\text { Conventional benchmark } \\
\text { (MSCI AC World) }\end{array}$ \\
Euro countries & & $1 / 8[0 / 2]$ \\
Austria & 9 & $4 / 2[0 / 0]$ \\
Belgium & 6 & $1 / 1[0 / 0]$ \\
France & 2 & $0 / 4[0 / 2]$ \\
Germany & 4 & $1 / 2[0 / 2]$ \\
Italy & 3 & $2 / 3[0 / 0]$ \\
Netherlands & 5 & $3 / 7[0 / 0]$ \\
UK & 10 & $1 / 6[0 / 2]$ \\
US & 7 & $13 / 33[0 / 8]$ \\
\hline
\end{tabular}

Panel B - Conditional World 3-Factor

Euro countries

\begin{tabular}{lrc} 
Austria & 9 & $1 / 8[0 / 2]$ \\
Belgium & 6 & $3 / 3[0 / 1]$ \\
France & 2 & $0 / 2[0 / 0]$ \\
Germany & 4 & $0 / 4[0 / 1]$ \\
Italy & 3 & $1 / 2[0 / 2]$ \\
Netherlands & 5 & $1 / 4[0 / 0]$ \\
UK & 10 & $2 / 8[0 / 2]$ \\
US & 7 & $1 / 6[0 / 2]$ \\
& & $9 / 37[0 / 10]$ \\
\hline Panel C - Conditional World Carhart 4-Factor & & \\
Euro countries & & \\
Austria & 9 & $1 / 8[0 / 5]$ \\
Belgium & 6 & $3 / 3[0 / 1]$ \\
France & 2 & $0 / 2[0 / 1]$ \\
Germany & 4 & $0 / 4[0 / 2]$ \\
Italy & 3 & $0 / 3[0 / 2]$ \\
Netherlands & 5 & $2 / 3[0 / 0]$ \\
UK & 10 & $3 / 7[0 / 1]$ \\
US & 7 & $0 / 7[0 / 4]$ \\
& & $9 / 37[0 / 16]$ \\
\hline
\end{tabular}

